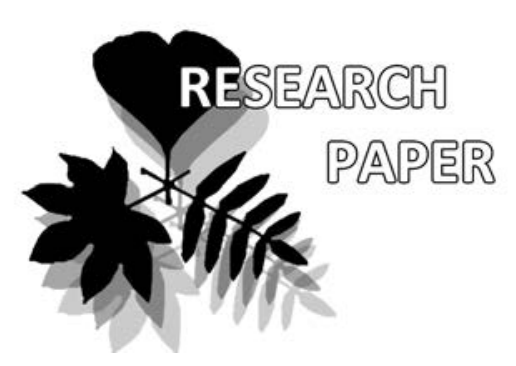

Ivan A. Savinov ${ }^{1 *}$

e-mail: savinovia@mail.ru

Nikolai A. Trusov

e-mail:n-trusov@mail.ru

${ }^{1}$ Moscow State University of Food Production, Moscow, 125080, Russia

${ }^{2}$ Tsytsin Main Botanical Garden RAS, Moscow, 127276, Russia

Manuscript received: 09.04.2018 Review completed: 10.10.2018 Accepted for publication: 30.10 .2018 Published online: 01.11.2018

\section{Far Eastern species of Euonymus L. (Celastraceae): additional data on diagnostic characters and distribution}

\author{
Ivan A. Savinov ${ }^{1 *} \&$ Nikolai A. Trusov ${ }^{2}$
}

\begin{abstract}
A B S T R A C T
A critical analysis of morphological characters with special focus on degree of variability for closely related taxa allowed to justify the boundaries between representatives of the Euonymus growing i the Russian Far East. Clear morphological characters for 11 species were found and a key for species identification in field conditions is suggested. The species status for E. maximowiczianus, E. $\times$ miniatus, E. pauciflorus, E. planipes, E. sacrosanctus and E. sieboldianus has been proved.

Ke y w o r d s : Russian Far East, China, Korea, Japan, Euonymus, Celastraceae, morphological analysis, variability, hybridization, geographic distribution

\section{P E 3 Ю M E}

Савинов И.А., Трусов Н.А. Аальневосточные виды рода Euonymus L. (Celastraceae): Аополнительные данные о диагностических признаках и распространении. Критический анализ морфологических признаков с особым вниманием к степени их изменчивости позволиц обосновать границы межАу отдельными представителями рода Eиопутия, распространенными на российском Аальнем Востоке. Выявлены четкие морфологические признаки Аля 11 видов и созАан кАюч Аля их полевого определения. Обоснован виАОвой статус следующих таксонов: E. maximowiczianus, E. $\times$ miniatus, E. pauciflorus, E. planipes, E. sacrosanctus и E. sieboldianus.

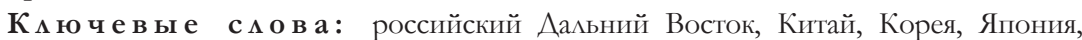
Euonymus, Celastraceae, морфологический анализ, изменчивость, гибриАизация, географическое распространение
\end{abstract}

From 15 to 16 species of Euonymus L. are known in the flora of Russia now (Savinov 2009, 2011). Of them, 11 species are distributed in the Russian Far East (Sakhalin island, Amur region, Primorskyi Krai, southern Kuril Islands). In the last taxonomical treatment of the genus Euonymus by Ma (2001) who did not analyze speciments from Russian herbaria, many species from Russia were treated as synonyms to other species. As a result, Ma accepted only 5 species from the Russian Far East. According to Ma's opinion, E. sachalinensis (F. Schmidt) Maxim. is polymorphic taxon that includes E. maximowicziana Prokh., E. planipes (Koehne) Koehne, E. sachalinensis and E. $\times$ miniata Tolm.). Same solutions were applied in the "Flora of China" (Ma \& Funston 2008). Thus, the search for good diagnostic characters remains important for understanding the diversity of the genus Euonymus and for clarification of geographical distribution of some taxa. Another problem discussed in this paper is hybridization between some species from Kalonymus subgenus (E. macropterus, E. sachalinensis). Taxonomical boundaries between closely related species and status of hybrid samples also remain questionable.

\section{MATERIALS AND METHODS}

The study is based on critical analysis of herbarium materials from LE, MW, MHA, MOSP, MW, KW, MSUD, VLA, NS and personal collections from the region (deposi- ted in MHA). Many herbarium specimens were examined and re-identified that allowed us to specify the details of the geographical distribution of species. Original data were obtained during field trips to Sakhalin island and Primorskyi Territory (Sikhote Alin mountain, southern part of Khassansky district) in July-August 2007 and September-October 2017.

Taxonomy of species treated follows to International plant name index (https://www.ipni.org/). Categories of types for all studied species are given according to the Leonova (1974).

\section{RES U LTS}

According to this treatment, we accept following 11 species of Euonymus in the Russian Far East:

1. Euonymus maackii Rupr. 1857, Bull. Phys.-Math. Acad. Sci. Petersb. 15: 358; Ma 2001, Thaiszia - J. Bot., 11: 182; Ka 2006, New Fl. Korea (Lee) 1: 713; Ma, Funston 2008, Fl. China 11: 459.

Syntypi: "Amurae flumen ad ostii Zeae et Bureae 14 VI 1855 R. Maak", "Amurae flumen ad ostium Ussuriae 4 IX 1855 R. Maak" (LE!).

Ecology and distribution: In river valleys, on the slopes. Eastern Siberia (Dahuria); the Russian Far East: Amur River basin in Khabarovskyi Krai, western and southern parts of Primorskyi Krai. Mongolia, north-eastern regions of China, Korean Peninsula. 
2. Euonymus sieboldianus Blume 1827, Bijdr. Fl. Nederl. Ind.: 1147; Ohwi 1984, Fl. of Japan: 604. - E. hamiltonianus Wall. sensu Ma 2001, Thaiszia - J. Bot., 11: 165; Ka 2006 , New Fl. Korea (Lee) 1: 715; Ma, Funston 2008, Fl. China 11: 457, pro parte.

Typus: "Japonia, P.F. Siebold" (L). Note: in the opinion of Blakelock (1951), type specimen at Leiden belong to E. hamiltonianus Wall. s.l.

Ecology and distribution: At the edge of the forests in river valleys. The Russian Far East: Southern Sakhalin, Moneron island, Iturup, Kunashir. Japan, Korean Peninsula.

Notes: Euonymus maackii and E. sieboldianus have Himalayan links and closely related to E. hamiltonianus Wall., with which they are often united. For example, Ma (2001) included E. sieboldianus Blume in the synonyms of E. hamiltonianus.

3. Euonymus pauciflorus Maxim. 1859, Mém. Prés. Acad. Sci. Pétersb. Div. Sav. 9: 74 (Prim. Fl. Amur.); Ka 2006, New Fl. Korea (Lee) 1: 714 - E. verrucosus Scop. sensu Ma 2001, Thaiszia - J. Bot., 11: 221; Ma, Funston 2008, Fl. China 11: 462, pro parte.

Syntypi: "Amurae, Poddale, silvarum frondosarum humido 19 V 1855 K. Maximowicz", "Amurae, Dzifuae, in crescentes fruticosis um solum arenosum VII $1855 \mathrm{~K}$. Maximowicz" (LE!). Note: Both specimens are arranged on the same herbarium sheet.

Ecology and distribution: In the forest undergrowth, usually on the wet habitats. The Russian Far East: valley of Amur River in Khabarovskii Krai, Primorskyi Krai (especially in central and southern districts). North-eastern regions of China, northern part of Korean Peninsula.

Notes: The species closely related to European taxon, E. verrucosus Scop., from which it differs by densely pubescent leaves on both sides and the length of the pedicels of lateral flowers in the inflorescences. Both taxa are vicarious species, one in Europe and another in the Far East.

4. Euonymus alatus (Thunb.) Siebold 1827, Syn. Fl. Oecon. Jap.: 49; Ohwi 1984, Fl. Jap., revised ed.: 603; Ma 2001, Thaiszia - J. Bot., 11: 75, pro parte, excl. sp. E. sacrosancta Koidz.; Ka 2006, New Fl. Korea (Lee) 1: 711; Ma, Funston 2008, Fl. China 11: 448.

Typus: "Japonia, non procul Nagasaki, Satsumae" (UPS).

Ecology and distribution: On the slopes and on the rocks along the rivers, near sea coast, bushes, bamboo, near hot springs. The Russian Far East: Southern Primorye, Southern Sakhalin, southern Kuril islands (Urup, Iturup, Kunashir). Japan, Korean Peninsula, China.

5. Euonymus sacrosanctus Koidz. 1925, Bot. Mag. Tokyo 39: 12. - E. alatus (Thunb.) Siebold sensu Ma 2001, Thaiszia - J. Bot., 11: 75.

Typus: "Japonia, Prov. Shinano, Zenkoji, mt. Ohminesan, leg. J. Matsumura! Julio 9, 1884" (KYO).

Ecology and distribution: In the forest undergrowth, among shrubs on fringes and felling, in the river valleys and brooks. Eastern Siberia (valley of the Irkut river, Dahuria); the Russian Far East: valley of the Amur river, central and southern parts of Primorskyi Krai, Southern Sakhalin, Moneron island. Korean Peninsula, China.

Notes: This taxon differs very well from $E$. alatus by thin leaves, fimbriate-serrate (ciliate) on the margin, from the underside on the whole surface they are pubescent, and on the upper side over the main vein densely pubescent, the inflorescences are simple dichasia, 1-3-flowered (for E. alatus - 3-7-flowered), therefore deserves a species status. It is necessary to clarify the data on the distribution of the species in Japan, from which the type specimen is known.

6. Euonymus maximowiczianus Prokh. 1949, Fl. URSS, 14: 744, nom. altern. - E. sachalinensis (F. Schmidt) Maxim. sensu Ma 2001, Thaiszia - J. Bot., 11: 34.
Typus et isotypus: "Prov. Ussuriae, Possjet, crescentes fruticosis ad clivo saxoso 7 VII 1860 K. Maximowicz" (LE!).

Ecology and distribution: In the forests, forest edges. The Russian Far East: Southern Primorye (south of the Bolshaya Ussurka River). Adjacent areas of China and North Korea. In the "New flora of Korea" (Ka in Lee Yong No 2006: 715) the photograph of E. maximowicziana Prokh. (with opened capsules and 5-merous flowers with white petals) is placed and entitled "E. sachalinensis (Fr. Schm.) Maxim. (incl. E. planipes (Koehne) Koehne)"!

Notes: The species has good morphological characters, namely: the leaves are rhomboid-elliptical or ovate, along the margin are finely or doubly serrate; flowering shoots 4-7.5 cm long; a capsule 8-10 $\mathrm{mm}$ in diameter, with rounded-triangular wings $2-4 \mathrm{~mm}$ in length. From E. sachalinensis it differs habitually, having the appearance of a large sprawling shrub or a small tree. This species differs well from E. planipes also by shape of wings on the capsule. Voroshilov (1982) considered E. maximowicziana a synonym of E. planipes.

7. Euonymus planipes (Koehne) Koehne 1906, Mitt. Deutsch. Dendr. Ges. 15: 62; Ohwi 1984, Fl. Jap., revised ed.: 605. - E. sachalinensis (F. Schmidt) Maxim. sensu Ma 2001, Thaiszia - J. Bot., 11: 34.

The species was described from cultivated specimens in Berlin, grown from seeds which were collected in Japan.

Ecology and distribution: on the river valleys, on forest edges, on the slopes. The Russian Far East: South-Western Sakhalin, southern Kuril islands (Iturup, Kunashir). Japan (Hokkaido, Honshu), Korean Peninsula.

Notes: The species is well distinguished by the following diagnostic characters: the leaves are oblong-obovate and broadly elliptic, along the margin they are large and sharply double-serrated; flowering shoots 6-13.5 cm long; capsule $10-15 \mathrm{~mm}$ in diameter, with very short rounded wings 2-3 $\mathrm{mm}$ in length (the fruit on the side, especially on the herbarium material, usually has a heart-shaped shape!). All studied samples collected in the south and west of Sakhalin, as well as in the southern Kuril islands (Iturup, Kunashir) and defined by many collectors as E. yesoensis Koidz. (= E. oxyphylla Miq.) belong to E. planipes. This mistake, apparently, is due to the fact that the E. planipes lobed capsule, which has very short but noticeable wings, was considered as a wingless non-lobed (sometimes slightly angular, with angles of $1 \mathrm{~mm}$ wide) spherical ones of E. oxyphylla.

8. Euonymus macropterus Rupr. 1857, Bull. Phys.-Math. Acad. Sci. Petersb. 15: 358; Ohwi 1984, Fl. Jap., revised ed.: 604; Ma 2001, Thaiszia - J. Bot., 11: 28; Ka 2006, New Fl. Korea (Lee) 1: 714; Ma, Funston 2008, Fl. China 11: 443. - E. ussuriensis Maxim. 1881, Bull. Acad. Imp. Sci. SaintPetersbourg, sér. 3 27: 449.

Typus: "Inferior Amurae, supra fluminis Kurfiae, in declivis saxoso riparia, in silvis intermixti 7 VIII 1855, R. Maak" (LE!).

Ecology and distribution: Very common in the forest edges, especially in river valleys and on the slopes. The Russian Far East: Amur valley, Primorye, southern Sakhalin, southern Kurils (Urup, Iturup, Kunashir, Shikotan). Japan (Hokkaido, Honshu), Korean peninsula, northeast China.

Notes: Among the Far Eastern species this one is the tallest and usually has the appearance of a large tree (rarely a spreading shrub). Flowers are 4-merous.

9. Euonymus sachalinensis (F. Schmidt) Maxim. 1882, Bull. Acad. Sci. Petersb. 27: 446; Ma 2001, Thaiszia - J. Bot., 11: 34, pro parte, excl. sp.: E. maximowicziana Prokh., E. planipes (Koehne) Koehne, E. × miniata Tolm.; Ka 2006, New Fl. Korea (Lee) 1: 715; Ma, Funston 2008, Fl. China 11: 443. - E. tricarpus Koidz. 1916, in Matsum. Ic. Pl. Koisikav. 3: 77, t. 184, pro parte; Ohwi 1984, Fl. Jap., revised ed.: 605, pro parte. 
Lectotypus: "Insula Sachalin, Due, 12 Juni 1860 F. Schmidt" (LE!). Note: when the first author reviewed the available material in LE, it turned out that the labels do not match the specimens, since the dates of collection (early summer) and the appearance (fruiting shoots) are clearly in disagreement with each other.

Ecology and distribution: Tends to grow on humic soils on the lower part of the slopes covered by mixed coniferbroad-leaved forest, especially with Betula ermanii Cham. The Russian Far East: Central and Southern Sakhalin, southern Kurils (Urup, Iturup, Kunashir). Japan (Hokkaido, Honshu).

Notes: The species differs habitually (a short, often creeping shrub) and the wings of a capsule, usually sharply deflected to its base, and whose length is not more than $1 / 2$ of the diameter of the fruit. Other characters: the leaf blades are smooth, elliptical or roundish, large irregularly crenateserrate or twice large-serrated, with a venation protruding from above and sharply protruding from below; flowering shoots 3-9 cm long; petals are dark purple; the capsule is 4-5-nested (sometimes 3-nested), with its wings strongly deflected to its base. On the northern border of the species area, in the Tymovskiy district of Sakhalin Province, the first author collected plants corresponding to E. sachalinensis (creeping shrub) by their habitat, and to $E . \times$ miniatus by the wings of capsule, which are horizontal or slightly deviated to the fruit base. This is a consequence of a deviation the hybrid taxon to one of the parental species.

10. Euonymus $\times$ miniatus Tolm. 1957, Bot. Mater. Gerb. Bot. Inst. Komarova Akad. Nauk S.S.S.R., 18: 159. - E. sachalinensis (F. Schmidt) Maxim. sensu Ma 2001, Thaiszia - J. Bot., 11: 34. - E. tricarpus Koidz. 1916, in Matsum. Ic. Pl. Koisikav. 3: 77, t. 184, pro parte; Ohwi 1984, Fl. Jap., revised ed.: 605, pro parte.

Syntypi: "Sachalinae, Dolinsk, in silvis intermixti, 15 VI 1952 A. Tolmachev", "Sachalinae, Dolinsk, in silvis intermixti, 18 VII 1952 A. Tolmachev et L. Motorina" (VLA!).

Ecology and distribution: Tends to the border of the forest and bamboo with Sasa kurilensis (Rupr.) Makino et Shibata, reaching the tops of low hills. The Russian Far East: Central and Southern Sakhalin, southern Kurils (Urup, Iturup, Kunashir). Japan (Hokkaido, Honshu).

Notes: It is a natural hybrid species between E. macropterus and E. sachalinensis and bears intermediate characters (Tolmachev \& Shukhobodsky 1963). Important of them are: leaf plates are wrinkled, ovate or obovate, small-serrate or twice crenate-serrate, the veins network from the top is not impressed and weakly protrudes from below; flowering shoots $2.5-16 \mathrm{~cm}$ long; petals dirty-violet or pale-lilac, spotted; capsule 4-5-nested, with wings usually straight or slightly deflected to the base.

11. Euonymus oxyphyllus Miq. 1865, Ann. Mus. Bot. Lugduno-Batavi 2: 86; Ohwi 1984, Fl. Jap., revised ed.: 605; Ma 2001, Thaiszia - J. Bot., 11: 29; Ka 2006, New Fl. Korea (Lee) 1: 714; Ma, Funston 2008, Fl. China 11: 443. - E. yesoensis Koidz. sensu auct. Japon.

Typus: Japonia, Keiske (L)

Ecology and distribution: In the dense thick forests and in the bush, on the mountain slopes. The Russian Far East: Kunashir Island (once collected!). Japan, Korean Peninsula, China.

Notes: This is the only representative of the genus Euonymus in the flora of Russia, which has a globular non-locular capsule and at the same time belongs to the subgenus Kalonymus. There is a unique collection from the Kunashir Island, given in the work by Tatewaki (1957) and quoted by Barkalov (2009): "Chachanupuri, Isl. Kunashiri, K. Kondo, Jul. 20, 1929 (Herb. Hiroshii Harae)" and kept in the Herbarium of the University of Sapporo (SAPS). It should be noted that this collection made it possible to a number of authors to indicate the species for the Kunashir Island (Voroshilov 1966, 1982, Ohwi 1984, Nedoluzhko 1995). New collections in nature are required!

\section{The key for identification of the Far Eastern species of the genus Euonymus}

1. Vegetative buds usually ovate, apical about $5-8 \mathrm{~mm}$ long, scales along the edge ciliate. Inflorescences 3 -axised (without additional axis). Stamen filaments well developed, anthers 2 -nested. The capsule is wingless, often with the remainder of the column at the apex. Seeds are not hanging (subgenus Euonymus) ......................................................... 2.

- Vegetative buds narrow-lanceolate or fusiform, apical than $10 \mathrm{~mm}$ long, scales along margin not ciliate. Inflorescences 5-axised. Stamen filaments in the form of a tubercle, anthers 1-nested. The capsule is winged (very rarely is wingless), without the remainder of the column. Seeds hang on a short funicle (subgenus Kalonymus Beck) .............................. 6.

2(1). Shoots with well-noticeable numerous cork warts; leaves densely pubescent ................ E. pauciflorus Maxim.

- Shoots without warts; leaves not densely pubescent ...... 3.

$3(2)$. Shoots usually carry wing-like corky outgrowths (rarely cork warts). The flowers are greenish-yellowish, with an ovary deeply embedded in the nectar disk, with very short stamens and a column. The capsule is divided into 1-2 (3) lobes almost to the base

- Shoots more often without wing-like cork outgrowths. Flowers with other characters. Anthers are purple. Capsule is lobed

5.

4(3). Leaves are coriaceous, crenate or small-sawed on the margin, glabrous on both sides

E. alatus (Thunb.) Siebold

- Leaves are thin, fringed-serrate (ciliate) along the margin, bottom along the whole surface, and densely pubescent on top of the main vein

E. sacrosanctus Koidz.

5(3). Leaf blades and capsules are glabrous

E. maackii Rupr.

- Leaf blades pubescent, capsules densely covered with papillate trichomes ................................. E. sieboldianus Blume

6(1). Flowers are 4-merous. Capsule 4-nested, with long narrow wings, exceeding in length its diameter and deflected towards its apex

E. macropterus Rupr.

- Flowers 5-4-merous on the same plant individual. Capsule 5-4-nested (sometimes 3-nested) ……………................ 7.

7(6). The capsule is spherical, wingless and not lobate ........... E. oxyphyllus Miq.

- The capsule with wide wings not exceeding its diameter .. 8.

$8(7)$. Petals are greenish-white or cream. The wings of the capsule are horizontal, not exceeding half of its diameter along the length

9.

- Petals are purple or dirty purple. The wings of the capsule are usually deflected to its base and exceed half of its diameter along the length .

10.

9(8). The leaves are rhomboid-elliptical or ovate, along the margin of small or double-serrated. Flowering shoots 4-7,5 cm long. Capsule $8-10 \mathrm{~mm}$ in diameter, with rounded-triangular wings 2-4 $\mathrm{mm}$ long

E. maximowiczianus Prokh.

- Leaves oblong-obovate and broadly elliptic, large- and sharp-, double-serrate at the margin. Flowering shoots 
6-13.5 cm long. Capsule 10-15 $\mathrm{mm}$ in diameter, with very short rounded wings 2-3 $\mathrm{mm}$ in length

E. planipes (Koehne) Koehne

10(8). Leaf blades smooth, elliptical or rounded, large irregularly crenate-serrate or twice large-ciliated, with a denticular vein network protruding from above and sharply extending from below. Flowering shoots 3-9 cm long. Petals are dark purple. Capsule 4-5-nested (sometimes 3-nested), with wings strongly deflected to its base

\section{E. sachalinensis (F. Schmidt) Maxim.}

- Leaf blades are wrinkled, ovate or obovate, finely serrate or twice crenate-serrate, the veins network from above is not impressed and weakly protrudes from below. Flowering shoots $2.5-16 \mathrm{~cm}$ long. Petals are dirty-violet or pale-lilac, spotty. Capsule 4-5-nested, with usually straight or slightly deflected wings to the base

E. $\times$ miniatus Tolm.

\section{PHYTOGEOGRAPHIC COMPARISONS}

The critical analysis of the characters used in species diagnoses and the re-identification of herbarium specimens allowed to prove species status for E. maximowiczianus, E. $\times$ miniatus, E. pauciflorus, E. planipes, E. sacrosanctus and E. sieboldianus and specify their geographical distribution in the Far East of Russia. Examination of specimens brought us to conclusions, which are opposite to opinion of $\mathrm{Ma}$ (2001). The results of this study show that these species are well distinguishable from each other, as well as from close species by the position of capsule wings and by capsule shape (Figs 1-3). The characters of the structure of vegetative organs (the form of growth, the peculiarities of the shoots, the shape of the buds, the shape of the leaves, the shape of their margin and apex, the degree of their pubescence) are also rather stable within species and are important for species identification that was shown by Kim \& Kim (1994). New data expanded the list of diagnostic characters of studied species and peculiarities of their distribution, given in the treatment by Kiseleva (1988).

From 11 accepted species 8 are characteristic to Sakhalin and southern Kurils. Of them, 7 species are distributed in southern Kurils (Barkalov 2009) and 6 in mainland part of the Russian Far East; 3 species are common for both regions. None of Euonymus species mentioned above are endemic for Russia, as they are also common in adjacent areas of China, North Korea and Japan.

As a result, the most important diagnostic characters in the genus Euonymus used in making taxonomic decisions are: morphology of inflorescences, the shape and color of flower, the shape of capsule, the shape of aril (see: Prokhanov 1949, Blakelock 1951, Leonova 1974, Ma 2001, Savinov 2009).

In recent time specialists in the field of molecular phylogenetics have also become interested in the genus Euonymus (Li et al. 2014), in their analysis included 48 species, among which those growing on Russian Far East (E. alatus, E. maackii, E. macropterus, E. oxyphyllus). The monophyly of the subgenus (sect.) Kalonymus has been demonstrated. They also discuss the problem of interspecific hybridization in the genus: "the possibility of secondary contacts of split lineages (species) ... should not be completely ruled out, although no solid evidence of interspecific hybridization was found in

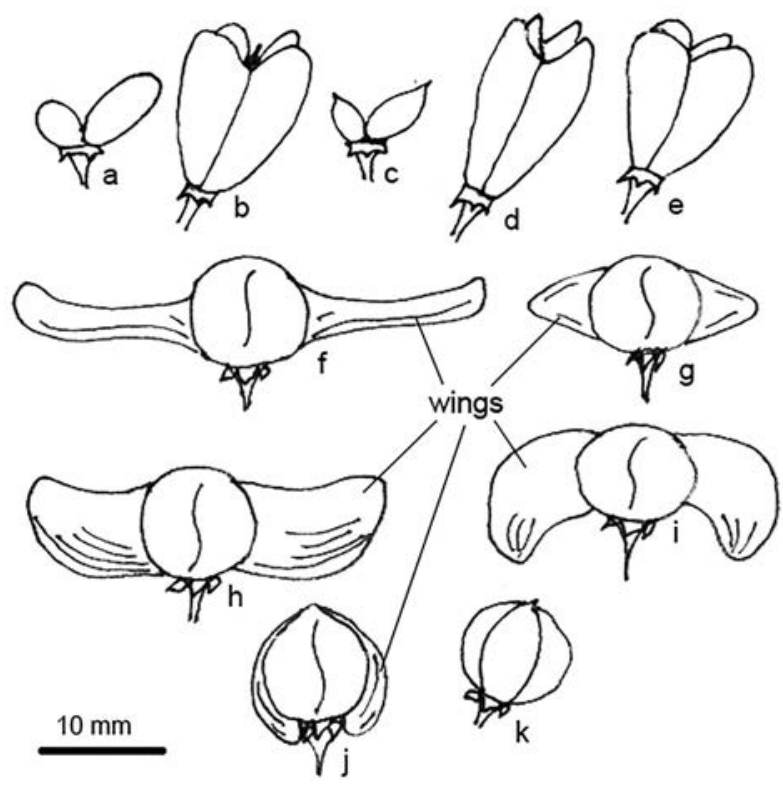

Figure 1 Shape of capsules and wings position for studied species of Euonymus from the Russian Far East (schematized): a - Euonymus alatus, b - E. sieboldianus, c - E. sacrosanctus, d - E. pauciflorus, e - E. maackii, f - E. macropterus, g - E. maximowiczianus, $\mathrm{h}$ E. $\times$ miniatus, $\mathrm{i}-$ E. sachalinensis, $\mathrm{j}-$ E. planipes, $\mathrm{k}-$ E. oxyphyllus

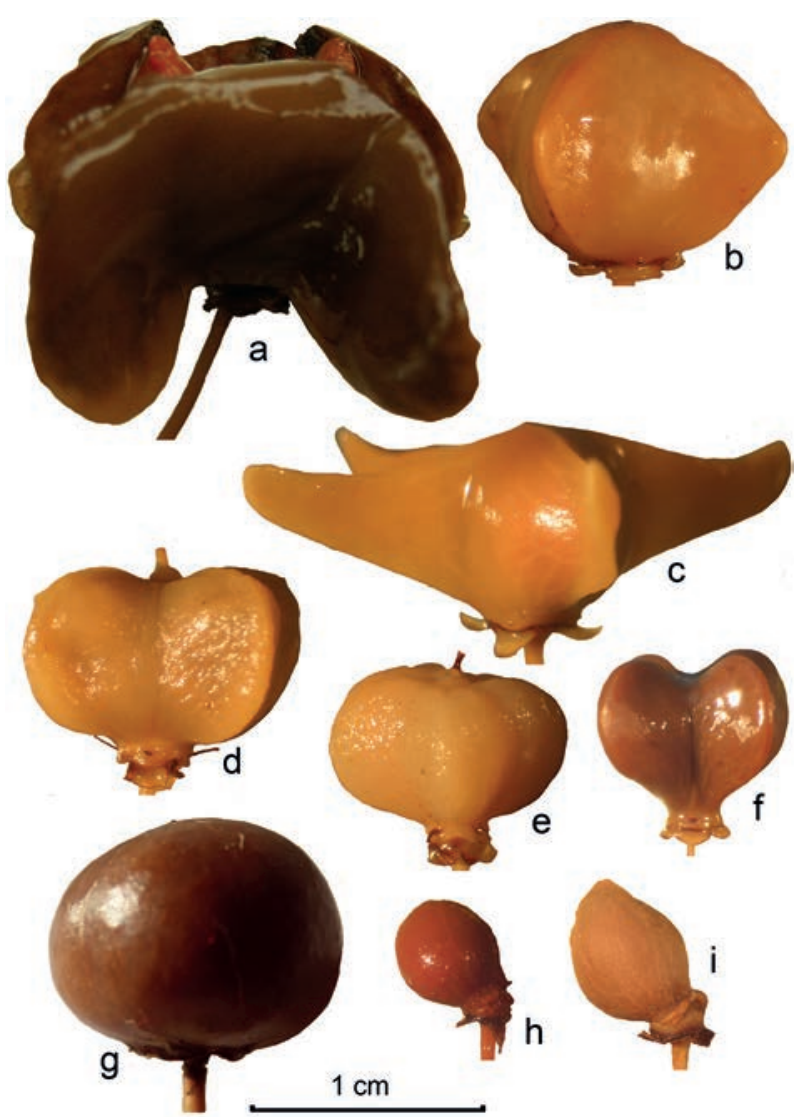

Figure 2 General view of capsules of some Far Eastern species of Euonymus (fixed material): a - E. sachalinensis; $\mathrm{b}-$ E. maximowiczianus; c - E. macropterus; d - E. sieboldianus; e - E. maackii; f E. panciflorus; $\mathrm{g}-$ E. oxyphyllus; $\mathrm{h}-\mathrm{E}$. alatus; $\mathrm{i}-\mathrm{E}$. sacrosanctus 


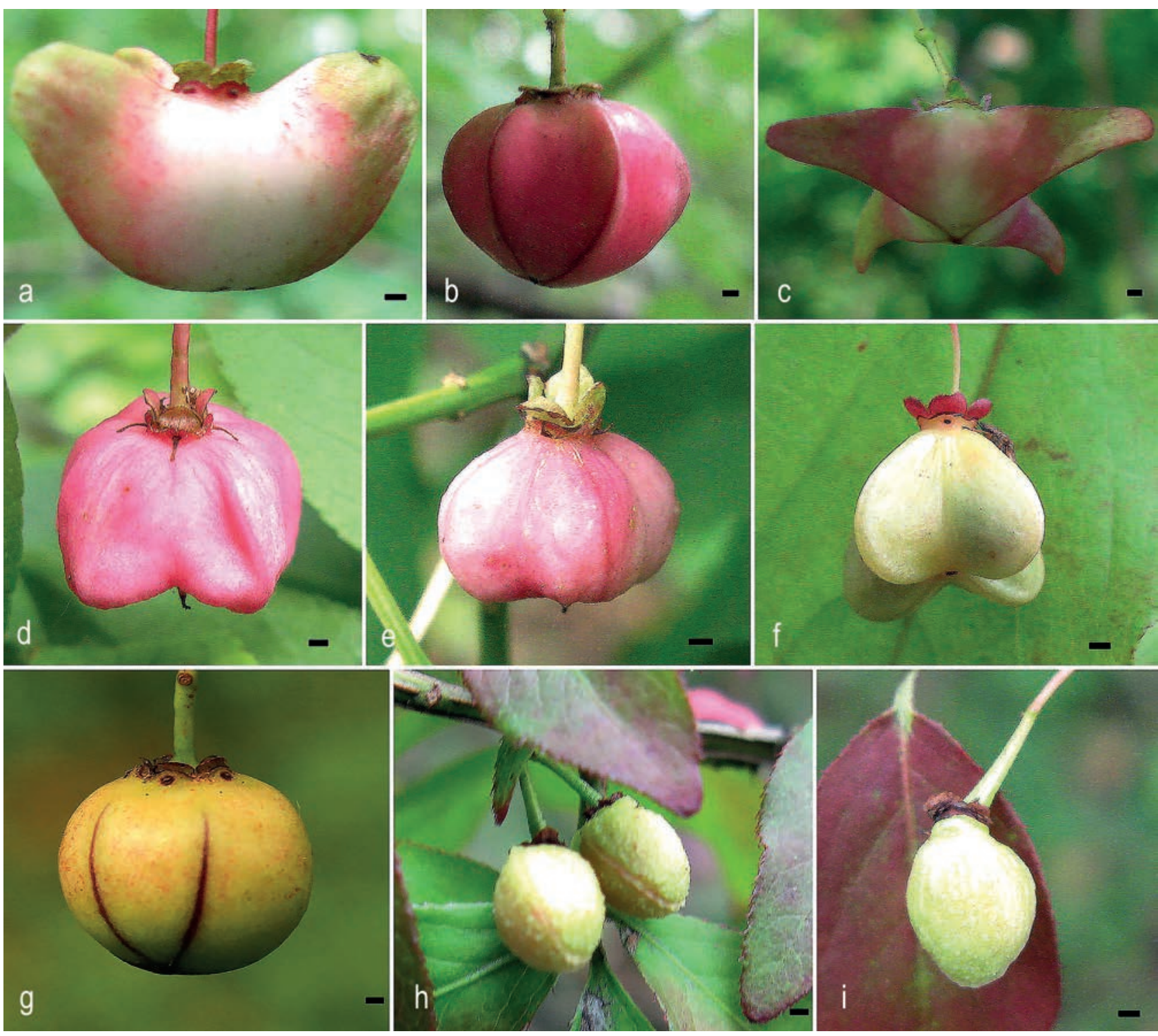

Figure 3 The fruits of some species of Euonymus in nature: a - E. sachalinensis; b - E. maximoniczianus; c - E. macropterus; d - E. sieboldianus; $\mathrm{e}-$ E. maackii; $\mathrm{f}-$ E. pauciflorus; $\mathrm{g}-$ E. oxyphyllus; $\mathrm{h}-$ E. alatus; $\mathrm{i}-$ E. sacrosanctus. Scale bar $-1 \mathrm{~mm}$

Euonymus" (Li et al. 2014: 157). This problem needs further study by traditional and molecular methods.

\section{ACKNOWLEDGEMENTS}

The first author expresses sincere gratitude to his colleagues from the Russian Far East, who rendered valuable assistance in organizing and conducting field research: A.A. Taran, V.V. Sheiko (Yuzhno-Sakhalinsk), T.A. Bezdeleva, O.A. Burkovsky, Yu.S. Polijchuk, V.Yu. Barkalov, V.A. Bakalin, Z.V. Kozhevnikova, V. Slabinsky, E.A. Pimenova, S.V. Nesterova, R.V. Dudkin (Vladivostok), I.V. Maslova, R.I. Korkishko, Yu.A. Melnikova (Kedrovaya Pad' Nature Reserve, Primorsky village).

\section{LITERATURE CITED}

Barkalov, V.Yu. 2009. Flora of the Kuril islands. Dalnauka, Vladivostok, 468 pp. (in Russian). [Баркалов B.Ю. 2009. Фцора Курильских островов. ВАадивосток: Аальнаука, 468 с.].
Blakelock, R.A. 1951. A synopsis of the genus Euonymus L. Kew Bulletin 2: 210-290.

Ka Nishikigi. 2006. Celastraceae. In: New flora of Korea, vol. 1. (Lee Yong No, ed.). Kyo-Hak Publ. Co., Ltd., Seoul, 709-716 pp.

Kim, J.H. \& Y.S. Kim 1994. A taxonomic study of Korean Euonymus L. (Celastraceae) based on the morphology of vegetative characters. Korean Journal of Plant Taxonomy 24(4): 215-230.

Kiseleva, K.V.1988. Family Celastraceae Lindl. In: Flora of the Soviet Far East, vol. 3 (S.S. Kharkevich, ed.). Nauka, Vladivostok, 152-159 рp. (in Russian). [Киселева К.В. 1988. Семейство Celastraceae Lindl. // ФАора советского Аальнего Востока / под реА. С.С. Харкевича. Т. 3. C. 152-159].

Leonova, T.G. 1974. The genus Euonymus L. of the USSR and neighbouring countries. Nauka, Leningrad, 132 pp. (in Russian). [Аеонова Т.Г. 1974. Бересклеты СССР и сопреАельных стран. $\Lambda .:$ Наука. 132 с.]. 
Li, Y.N., L. Xie, J.Y. Li \& Z.X. Zhang 2014. Phylogeny of Euonymus inferred from molecular and morphological data. Journal of Systematics and Evolution 52(2):149-160.

Ma, J.S. 2001. A revision of Euonymus (Celastraceae). Thaiszia - Journal of Botany 11(1/2):1-264.

Ma, J.S. \& A.M. Funston 2008. Celastraceae, Euonymus. In: Flora of China, vol. 11 (Oxalidaceae through Aceraceae) (Z.Y. Wu, P.H. Raven \& D.Y. Hong, eds.), pp. 440-463. Science Press, Beijing, and Missouri Botanical Garden Press, St. Louis. On-line version: http://www.efloras. org/florataxon.aspx?flora_id=2\&taxon_id=112340.

Maximowicz, C. 1881 (1882). Diagnoses plantarum asiaticarum, IV. Bulletin de la Classe physico-mathématique de l'Académie impériale des sciences de Saint-Pétersbourg 27: 439-460.

Nedoluzhko, V.A. 1995. The conspectus of the dendroflora of the Russian Far East. Nauka, Vladivostok, 208 pp. (in Russian). [Недолужко В.А. 1995. Конспект Аендрофлоры российского Аальнего Востока. ВАадивосток: Аальнаука. 208 c.].

Ohwi, J. 1984. Flora of Japan. Smithsonian Institution, Washington, $1067 \mathrm{pp}$.

Prokhanov, Ya.I. 1949. Family Celastraceae Lindl. In: Flora of the USSR, vol. 14. (V.L. Komarov, ed.), pp. 552-577 (in Russian) [Проханов Я.И. 1949. Семейство Celastraceae Lindl. // Фцора СССР / под реА. В.А. Комарова. T. 14. M.; $\Lambda .:$ AH CCCP, C. 552-577].

Prokhanov, Ya.I. 1960. The conspectus of system of the spindle-trees family of the USSR. Additions and changes. Botanicheskie Materialy Gerbariya Botanicheskogo Instituta AN USSR 20:409-412 (in Russian) [Проханов Я.И. 1960. Конспект системы бересклетовых СССР. Аобавления и изменения // Ботан. матер. герб. Бот. ин-та АН CССР. T. 20. C. 409-412].
Savinov, I.A. 2009. Taxonomic survey of the Celastraceae R.Br. family in Russian and Ukrainian floras. Bulleten' Moskovskogo Obshchestva Ispytatelei Prirody. Biologiya 114(2): 5868 (in Russian). [Савинов И.А. 2009. Таксономический обзор семейства Celastraceae R.Br. во флорах России и Украины // Бюлм. МОИП. ОтА. биол. Т. 114, вып. 2. C. 58-68].

Savinov, I.A. 2011. New data on the diagnostic characters and distribution of some Far Eastern species of Euonymus L. (Celastraceae R.Br.). In: Biodiversity and environment of Far East reserves 1: 66-70 (in Russian). [Савинов И.А. 2011. Новые Аанные о Аиагностических признаках и распространении некоторых Аальневосточных видов Euonymus L. (Celastraceae R.Br.) // Биота и среда заповедников Аальнего Востока. Вып. 1. С. 66-70].

Tatewaki, M. 1957. Geobotanical studies on the Kurile islands. Acta Horti gothoburgensis 21:43-123.

Tolmachev A.I., Shukhobodsky B.A. 1963. The spindle-tree genus (Euonymus) of Sakhalin Island. In: Trudy Sakhalinskogo kompleksnogo nauchno-issledovatel'skogo instituta 13: 1354 (in Russian). [Толмачев А.И., Шухободский Б.А. 1963. Бересклеты острова Сахалина // Труды Сахац. компл. н.-и. инст. Вып. 13. С. 13-54].

Voroshilov, V.N. 1966. The flora of the Soviet Far East. Nauka, Moscow, 478 pp. (in Russian). [Ворошилов B.H. 1966. ФАора советского Аальнего Востока. М.: Наука. 478 с.].

Voroshilov, V.N. 1982. Guide to the plants of the Soviet Far East. Nauka, Moscow, 672 pp. (in Russian). [Ворошилов B.H. 1982. Определитель растений советского Аальнего Востока. М.: Наука, 672 с.]. 